Article

\title{
ICT Use and Digital Inclusion among Roma/Gitano Adolescents
}

\author{
Maialen Garmendia ${ }^{1, *}$ and Inaki Karrera ${ }^{2}$ \\ ${ }^{1}$ Department of Sociology and Social work, University of the Basque Country, 20018 San Sebastian, Spain; \\ E-Mail: maialen.garmendia@ehu.eus \\ 2 Department of Didactics and School Organization, University of the Basque Country, 20018 San Sebastian, Spain; \\ E-Mail: inaki.karrera@ehu.eus \\ * Corresponding author
}

Submitted: 14 June 2017 | Accepted: 28 September 2018 | Published: 5 February 2019

\begin{abstract}
This article analyses the way in which the digital divide affects Roma/Gitano minors. This ethnic group is a paradigmatic case among socially underprivileged groups in Spain; excluded from industrial society, they appear to be facing a similar situation in the post-industrial era. We, therefore, sought to explore the digital experiences of minors from this group in order to study social and digital exclusion/inclusion among them. The research strategy took a comprehensive approach, covering both offline and online behaviour. We focused on the results of fieldwork undertaken in Spain during 2017. In all, interviews were conducted with 17 adolescents (aged 11 to 18) as well as with several social workers who were providing support to the minors. Given that the use of technology has become a prerequisite for the welfare of children and for the development of their rights, the issue tends to centre on three main areas, commonly known as the three Ps: provision, participation, and protection. As such, the analysis of inequality was based on these areas. The findings presented in this article illustrate that the use of ICTs can contribute to empowering Roma/Gitano adolescents to improve the position they occupy as a group in the social structure.
\end{abstract}

\section{Keywords}

adolescents; development; digital divide; Gitano; ICT; Roma; social inclusion; Spain

\section{Issue}

This article is part of the issue "Communicating on/with Minorities", edited by Leen d'Haenens and Willem Joris (KU Leuven, Belgium).

(C) 2019 by the authors; licensee Cogitatio (Lisbon, Portugal). This article is licensed under a Creative Commons Attribution 4.0 International License (CC BY).

\section{Introduction}

Digital literacy is now an essential factor in the welfare and rights development of children and young people. Increasingly, research into digital inclusion focuses on vulnerable groups, on the assumption that social exclusion can contribute to digital exclusion (Salemink, 2016). The debate on digital inequality encompasses both material and social inequalities (Van Deursen \& Van Dijk, 2013). However, the discussion extends beyond the classic vision of the "digital divide" between those who do and do not have digital devices and Internet access, given that such access is now a given in western societies, except in remote rural areas (Townsend, Sathiaseelan, Fairhurst, \& Wallace, 2013). This assumption of ubiquity means that it is now socioeconomic factors which play a dominant role in the non-use or limited use of digital applications (Salemink, 2016). This is one of the key issues in this regard. The "digital divide" is no longer marked by the possession of digital devices or Internet access; rather the inequality centres on the user's digital skills. It places the core of the issue with the user; that is to say, with their skill in accessing digital applications, being able to use them creatively and for their benefit (Mariën \& Prodnik, 2014). In this regard, gender, race, ethnicity, and social class can all be considered influential factors, determining individuals' resources and their capacity to access and use many digital appliances. Ethnic minorities, for example, face major limitations in accessing and using new devices due to linguistic and economic problems, among 
others (Gilbert, 2010; Halford \& Savage, 2010). The analysis of digital inequality, therefore, focuses on the digital inclusion of vulnerable and socially-excluded communities (Gilbert, 2010; Van Dijk, 2005).

\subsection{Roma/Gitanos as an Outsider Group}

Although civil servants, politicians and academics have highlighted the diversity of Romani groups, Matras (2014, p. 29) emphasizes the fact that "they share a sense of solidarity and common destiny. They are aware of similarities in language, customs and values, and in attitudes to family, work, shame and honour". Persistent stigmatisation and hostility from established groups have contributed to the reinforcement of their sense of shared culture inside the community as well as disidentification from those on the outside (Powell, 2013; Wacquant, 2012). Moreover, spatial separation such as ghettoization and educational segregation has reinforced the maintenance of physical, social, and emotional distance (Powell, 2013; Wacquant, 2012).

Powell (2016) describes Roma as an outsider group for whom stigmatisation and a perceived inferiority from the outside are almost perennial and universal aspects of their asymmetrical established-outsider relations; as he remarks, "how the relative lessening of power differentials experienced by many outsider groups over time, through functional democratization is much less apparent in the case of Roma" (Powell, 2016, p. 136).

Indeed, the European Union's efforts to promote Roma integration and "inclusion" have actually had unintended negative consequences in the form of "backdoor nationalism", whereby "old nationalist ambitions" are more openly expressed in some Central and Eastern European countries (Fox \& Vermeersch, 2010). According to De Swaan (1997), rather than identifying, GypsyTravellers/Roma tend to disidentify from the wider society, experiencing others as different from themselves. This attitude has caused fear and mutual avoidance strategies on the part of both the established communities and the outsiders: "the Gypsy-Travellers/Roma, in a bid to avoid harassment, contamination, and to preserve cultural practices central to their self-image; and the majority society which has attempted to avoid contamination and interaction with supposedly deviant, lazy, criminal, 'uncivilized', and inferior group" (Powell, 2016, p. 141).

The nature of the relations between the two groups has led to a peculiar functional interdependence, historically based on the traditional economic practices of Gypsy-Travellers/Roma which need the wider population as customers (Gmelch, 1986; Okely, 1983; Sibley, 1987). As Matras (2014, p. 58) states, therefore, "work provides the principal and often exclusive environment where Roms have contact with non-Roms". Sibley (1998) calls this "mixing without integration" and argues that Gypsies adapt in order to stay the same (see also Sibley, 1987).
The family is central to the internal social organisation of Gypsy-Traveller/Roma society. The extended, intergenerational family grouping performs specific and important functions in terms of socialization, cultural transmission, and protection from stigmatization. Many Gypsy-Travellers/Roma stay within their extended family groupings their whole lives, with young women being expected to join their husband's extended family group on marriage (Powell, 2016).

\subsection{ICTs for Development}

As this article's intention is to explore the role of ICTs in an outsider group's everyday life we need to avoid any ethnocentrism which would likely attribute the mainstream perception of social development to their development. Therefore, as Kleine (2013) emphasizes when referring to "technologies for development", development is the aim and ICTs are the means of achieving that aim. Drawing on Amartya Sen's capabilities approach, Kleine emphasizes that development should be seen as a process rather than an outcome; it is therefore necessarily ongoing and dynamic rather than fixed and static. It also implies freedom of choice in the personal, social, economic, and political spheres. This approach also "explicitly puts people at the centre of the development idea". Thus, people themselves should be the ones to define what type of life they value. This approach requires an open-ended process of deliberation which puts the views of the people whose lives are affected at the heart of the development process (Kleine, 2013, p. 4).

Although modernization theorists and policy-makers have traditionally tended to equate development with economic growth, on the assumption that wealth generated by economic growth would automatically trickle down to poorer segments of society over time, new discourses from welfare economists and ecologists among others tend to focus on social (Wilkinson \& Picket, 2009) or ecological sustainability (Nerfin, 1977). Consequently, Agenda 21-for instance-emphasizes the need for a balance between environmental, social, and economic aspects in order to achieve "sustainable" development (UN, 1992).

Kleine (2013) frames development within a peoplecentred approach, putting disadvantaged individualssuch as those with low-incomes, women and indigenous peoples-and their voices at the centre of her analysis. In Sen's (1999) capabilities approach, the focus of development is increasing a person's set of capabilities or their substantive freedom to lead a life that they have reason to value. Sen rejects so-called rational choice theory for its "simplicity of ignoring all motivations other than the pursuit of self-interest" (Sen, 2009, p. 187) and insists that choices are reason-based. Therefore, Sen's approach seems particularly suitable for exploring the ways in which ICT can contribute to increasing Roma/Gitanos' substantive freedom to lead a life they value. 


\subsection{ICTs for the Development of Roma/Gitanos Adolescents}

Roma/Gitanos are the largest ethnic minority group in Spain. Although no census breakdown is available for ethnic minorities, the Ministry of Health's registry suggests that there are between 570,000 and $1,100,000$ Roma individuals in Spain (Oleaque \& Moreno, 2017). This community has been living on the Iberian Peninsula since the fifteenth century. Contrary to popular belief, it is a relatively diverse community, and despite some large pockets suffering social exclusion, there is also a significant Roma/Gitano presence in modest or mediumlevel socio-economic layers. Nevertheless, Roma/Gitano people continue to be characterised by a situation of marginality, to such an extent that most belong to the poorest and most underprivileged social groups in Spanish society. Roma/Gitanos are a paradigmatic case among socially underprivileged groups; they were excluded from industrial society and the situation appears to be continuing in the post-industrial era (Granados, 2008). Most settled during the second half of the twentieth century when public policy promoted settlement as the first step towards their social integration (Leblon, 1993).

As stated in the Seventh Report on Exclusion and Social Development in Spain (Fundación Foessa, 2014, p. 188), an alarming percentage of the Roma/Gitano population are affected by social exclusion $(72.3 \%$ as compared to $23.5 \%$ among the non-Gitano population). Amongst Roma/Gitano households, this exclusion translates into income levels which are well below the overall average, higher unemployment, and major educational deficits.

The Spanish Roma/Gitano population joined the education system 30 years ago. Figures from the Roma Secretariat Foundation (Fundación Secretariado Gitano, 2013) show that in 2011, among Gitano students aged between 16 and 24, 64\% did not finish compulsory education as opposed to $13 \%$ among the wider student population. Moreover, $8.6 \%$ of the Roma population in Spain could not read or write and only $2.3 \%$ had postsecondary studies. Furthermore, the economic crisis has hit this group particularly hard, resulting in a decline in the level of household amenities. In a study by the Roma Secretariat Foundation carried out in collaboration with the National Drugs Plan, $22 \%$ of young Roma/Gitanos surveyed said they had had to dispense with home Internet connections for economic reasons.

The research presented here sought to discover the role played by digital technologies in Roma/Gitano children's everyday life, placing their voices at the centre of the analysis and seeking to determine how these technologies contribute to their personal and social development. Using Sen's (1999) approach, we defined development as increasing an individual's set of capabilities, or their substantive freedom to lead a life they have reason to value. We sought to explore how digital tech- nologies contribute to providing these children with a wider set of capabilities or choices. What are the choices they make when using these technologies? Who do they make contact with? What are their purposes when using these devices?

Given that the use of technology has now become necessary for the wellbeing of children and young people, as well as for the development of their rights, this analysis will focus on Internet access and use as a right. The UN Convention on the Rights of the Child (UNICEF, 2014) outlines the fundamental rights of children in three key areas-provision, participation, and protection-and this study, therefore, examines the relative capabilities of Roma/Gitano children and young people in these three domains.

\section{Research Method}

Our fieldwork also covered some other ethnic/nationality groups such as migrants from LatinAmerica, North and Sub-Saharan Africa, refugees, and children in foster care (UNICEF, 2018). Altogether, nearly one hundred people were interviewed, mostly children or adolescents but also a few community workers. Sampling was performed through different institutions providing support to social integration of these groups. Attempts were made to interview children from diverse socio-economic backgrounds in all the groups, however, it was not possible to achieve full representation in this sample. It must be noted that the findings of this article cannot be generalised to any of the entire populations concerned since those who are better off will presumably have little contact with such institutions.

This analysis of children's interaction with ICTs will focus on the situation of the members of the ethnic Roma/Gitano community as a particular case among those socially underprivileged groups. Mainstream research tends to focus on the capabilities of the individual user and has resulted in a somewhat narrow view of digital inclusion, insofar as it tends to individualize the issue. As Mariën and Prodnik (2014, p. 35) hold, "digital inclusion policies tend to individualize problems that are in fact social in their nature". Therefore, we decided to focus on Roma/Gitano children in view of their specific ethnic group traits which may influence their use of ICTs and their subsequent development of digital skills, such as their lack of involvement in secondary education and the control they set on young girls' behaviour.

We have opted for a contextualized and participative approach, centring on children. The fieldwork was conducted using a qualitative methodology enabling an indepth examination of these children's digital experiences in the context of their everyday life.

In order to ensure that all relevant themes were covered, the comprehensive interviews were based on a semi-structured conversation guide. Seventeen adolescents aged between 11 and 18 from an ethnic Roma/ Gitano background were interviewed at different loca- 
tions in the autonomous communities of Madrid and the Basque Country. We also interviewed two educators and one officer from institutions working with the groupsome of them belonging to the same ethnic group-to obtain a more complete overview of the social context of these children's interaction with digital technologies. All interviews were recorded in audio and transcribed.

\section{Main Findings}

As stated, our analysis of the information compiled from the interviews focuses on the three Ps-i.e., the three key areas of children's rights: provision, participation and protection. The Roma/Gitanos' rights to digital provision are basically related to having Internet access and using different devices in their everyday lives. Their rights to digital participation, on the other hand, are more related to the type of activities they perform online and their ability to communicate either within their community or outside it. As for digital protection, although theirs is a very supportive community, their parents usually lack the abilities to mediate their online activities effectively.

\subsection{Digital Provision}

Practically all the Roma/Gitano children interviewed have their own mobile phones/smartphones. Nevertheless, girls share their phone terminal with one of their parents more frequently than boys-in almost all cases, with the mother. Some girls said that if one of their parents' device were broken or lost, they would share their own phone with the parent. This is very unusual among adolescents from other ethnic groups, as there is ample evidence showing that privacy is highly valued at this age. Moreover, non-Roma children do not share mobile devices with their parents and tend to evade their surveillance (Haddon, 2015; Mascheroni \& Cuman, 2014). Nevertheless, insofar as far as girls are the ones who share their device, this seems to be one of the mechanisms used to control their behaviour, others will be mentioned in later sections of this article.

Despite having smartphones, Roma/Gitano children frequently have no Internet plan or data connection (or only have one on a sporadic basis). Many do not even have a Wi-Fi connection at home. They may have to share their parents' data allowance or go to the homes of friends or relatives in order to use their Wi-Fi network. They also used a variety of locations (such as community centres) where they could access free Wi-Fi:

\section{Interviewer: So you don't have Wi-Fi then?}

No. We only have the Wi-Fi on my father's mobile. He has the Internet and he lets us use his data [allowance]. (Boy, 15 years)

As for access to other devices, those that said they had a computer or tablet at home were the exception. Many mentioned "old" or "broken" computers that could no longer be used. Some children cited economic reasons for lack of access to such devices at home, freely admitting that their families could not afford to have a computer at home.

The absence of desktops or laptops in the home is a major impediment to doing normal schoolwork, especially among the older children who attend secondary school. As a result, they have to use the computers in the support classrooms at their schools, various social support centres (such as those run by the Fundación Secretariado Gitano), and even cyber-cafes to do their homework:

The school asks them to send in a lot of their work by e-mail, all the exercises they do at home....So many of them can't hand in all of their homework. That does interfere quite a bit with their studies. (Educator at the Fundación Secretariado Gitano)

However, Primary Education students seldom use computers at school. Most say they go to the computer room once a week where they are allowed to play or do whatever they want to; only a few say they use a word processor (for tasks such as writing recipes or stories) and only one boy mentioned looking up information online for schoolwork. Therefore, neither the frequency of the children's use of digital devices at school nor the type of activities they pursue appear to contribute much to the development of their digital skills.

We have ICT [class] once a week at my school and they let us do whatever we want-look for games and play them and things like that. They don't let us use social media, but we can search for games and music. And in English class, if we've been good for two days, on the third day the teacher lets us do whatever we want on the computer. (Girl, 11 years)

On the one hand, their online activity at school cannot be said to contribute much to developing new Internet skills. On the other, the children's discourse shows their lack of involvement in the education system, especially beyond puberty, reflecting the traditional aversion to institutionalised education among this ethnic group (Powell, 2016). As a general rule, they show little interest in formal education. Some freely admit that they have repeated a year more than once, not only for poor performance but also for bad behaviour. Moreover, among those who are of an age to have completed compulsory secondary education, a relatively large number acknowledge that they dropped out of school long before completing this cycle. None of them have a diploma and only a few are taking (or plan to take) complementary educational cycles and those who are, are following them somewhat erratically.

I've been doing cooking at high school for two years now.... started in first year and I had to repeat for bad 
behaviour.... And I just got into second year in Complementary, where I was doing cooking and I stuck with that. And then I did third year there. What I like most right now is cooking. (Boy, 16 years)

Interviewer: But didn't you tell me you were going to do carpentry?

There seems to be a clear association between the interviewees' school performance, their father's job or profession (or lack of it) and, as a consequence, the availability of ICTs in the home. As mentioned, lack of involvement in education is common among benefit-dependent families where the father is either unemployed or an itinerant trader who lacks sufficient devices and an internet connection. Indeed, nearly all the interviewee's families were benefit-dependent, and in order to receive their benefit allowance, such families are required to send their children to an educational institution. These young people will, therefore, have to attend school until they are 18 years old even if they have no interest whatsoever in the training on offer.

At the same time, there were a couple of boys who were committed to their school performance and aspired to gain the diploma in order to be eligible for vocational education cycles. In both cases, their fathers had a job and Internet skills. Among the interviewees, there was also one girl who said she planned to go on to post-compulsory secondary education. Although still very young, she was willing to work hard at school in order to have a career.

I'd like to become a hairdresser, but my mother wants me to become a lawyer.

Interviewer: Do you think there is any similarity between one and the other?

In all cases, you need some studies, and you have to pass all the subjects...

Interviewer: That's true.

And work hard. (Girl, 13 years)

This excerpt shows a very important change in attitude among some female members of the Roma/Gitano community. On the one hand, the girl's mother wants her daughter to get a university degree, and on the other, the girl was willing to work hard at school to gain a career. The type of degree the mother wanted her daughter to take is also significant; she wanted her to be able to provide professional support to other members of their ethnic group, just as her husband (the girl's father) does in his spare time (working in local government and collaborating with a foundation supporting Roma/Gitanos). An educator at the Fundación Secretariado Gitano also noted a major change among some young Gitano boys and girls who were outperforming their peers at university and taking an active part in these institutions. These young people are acting as ambassadors for their community and trying to solve its problems.

\subsection{Digital Participation}

The purposes for which Roma children use their mobiles/smartphones are quite similar to those of any other children of their age. They mentioned WhatsApp as a basic tool for chatting to friends and relatives; as Boyd and Ellison (2007) found, teenagers use their mobile devices and social media to coordinate and activate their offline social life. The interviewees' social life is limited to their extended family and ethnic group. Some of them mention they may have friends at school, but most of their relationships take place among their community members, reflecting their strong group orientation.

Recreational use clearly predominates: playing games, listening to music, and watching videos. Many follow popular YouTubers such as 'Auronplay' and 'El Rubius'. Their activity is very restricted, and their searches focus almost exclusively on entertainmentrelated themes, such as fashion and beauty, football, and music.

Mostly for listening to songs. Reggaeton and all that, you know? The stuff that's popular at the moment. Apart from that, I don't know....For example, you can get stuff on how to make your hair grow or how to make it stronger, or funny videos and things. (Girl, 12 years)

Their use of other applications is very limited, and they seem to use social media (except for WhatsApp) substantially less than average when compared to other Spanish children of their age group (Garmendia, Jiménez, Casado, \& Mascheroni, 2016). This is especially true of the girls, as very few use social media and many freely acknowledge that their parents and brothers do not allow them to have a profile on Facebook or Instagram - a very common situation in Roma/Gitano communities which strongly regulate young girls' behaviour (Matras, 2014).

Most interviewees say their level of knowledge when it comes to mobile phone use is "normal", but much more limited in the case of computers. They accept that not having a computer at home places them at a disadvantage vis-à-vis other children who have one. Most of them are not aware of the potential advantages of developing digital skills or possible uses of the Internet other than those related to communication and entertainment, confirming Toyama's theory of the Law of Amplification in technology, which holds that people's use of technology tends to reinforce their own interests (Toyama, 2015). Therefore, if Roma/Gitanos are not committed to their school activities they will show no interest in using technology for learning. 
I don't know what help it would be to use the mobile well; I'm happy with the way I'm using it now. The only thing I use it, for now, is WhatsApp; I don't even log on to Instagram any more. (Boy, 16 years)

Thus, the children generally do not have digital skills and do not value them; as a result, they have no interest in developing them. However, there are some exceptions; some of the older children said they would like to "learn a bit more about computers". Some even say that technology will be very important in the future, but this discourse appears to be somewhat empty as it lacks a connection with their own future actions.

Interviewer: And in the future, when you're older, maybe when you're in work, do you think it will be important to know about these things?

Yes, I do think it's important.

Interviewer: And would you like to find out more?

Well yes, a bit, because I don't know much. To be honest I don't know much about computers. And I'd like to learn a bit more. (Boy, 16 years)

In general, when asked about themselves compared to their non-Gitano peers they are quite reluctant to acknowledge differences in social or economic terms; on the contrary, they tend to stress the similarities as far as their rights are concerned. They emphasize that they do not like comparing their ethnic group with others and claim they do not like to "differentiate" among people. In contrast, however, they often proudly state they are culturally different. They claim to be similar in terms of rights, yet culturally different.

\subsection{Digital Protection}

Most Gitano children say they have accessed the Internet with little or no supervision. They generally say their parents have little or no knowledge of the Internet, although they are warned frequently of the potential dangers. However, these warnings are not often accompanied by clear guidelines. In the long term, some prohibitions could end up simply keeping them off the Internet rather than helping them to avoid or cope with possible risks. Parents who lack digital knowledge or skills may end up restricting or even forbidding their children's use of ICTs.

They think they have to work on security with their children. But I think they don't have the tools they need. They don't know to what extent the Internet is or isn't harmful for kids. We recently heard about one father who wouldn't let his daughter come to an IT course because he said the computer was the devil. (Educator at the Fundación Secretariado Gitano)
The lack of mediation frequently translates into a lack of any restrictions on mobile phone use, which can result in excessive and uncontrolled use. The most immediate consequences of overuse may be that the children neglect their schoolwork or even spend less time with their friends. A few young girls openly stated that they spend 'all day' online and another boy said his father had to switch off the Wi-Fi because otherwise, he would not go to sleep.

The lack of mediation may be related to an absence of digital skills among parents, especially in the case of mothers. Many mothers only have a simple (non-data) mobile phone. Others have a smartphone but do not know how to make the most of it.

In any case, all but a very few of the children said they were more skilful than their parents at using technology. This absence of skills among their parents means that many of the interviewees are self-trained. They often mention using online tutorials for learning as well as getting help from friends or older siblings.

However, it is striking that despite this lack of digital skills among parents, all the children unhesitatingly say that in the event of a serious problem, they would turn to their parents and the rest of the family. In their discourse, all interviewees displayed great respect for their parents and their extended family and said they were willing to comply with all the rules related to the use of phones at mealtimes and girls' offline behaviour and online self-image.

With regard to potential online risks, those most frequently cited by the children were attempts by strangers to make contact with them. They are usually very cautious and do not accept friend requests other than from people they know well.

They also mentioned different forms of harassment. On occasions, episodes of bullying may come from among members of the same community.

Although hate speech against the Roma/Gitano community is widespread on the Internet, the children mentioned hardly any cases of encountering online content that offended them as Roma. Nonetheless, some children did mention situations in which they had been insulted for this reason:

Once I was in a group from my class and one of them called me a fucking gypsy. He said it a few times on the mobile. I didn't pay any attention, I just let him talk. But the next day he said it again and we had a fight.

Interviewer: Does that often happen to you and other Roma friends of yours?

$$
\text { Yes. (Boy, } 16 \text { years) }
$$

Although this section is primarily concerned with child protection regarding their digital habits, specific mention should also be made of the protection and regulation of the behaviour of girls in the Roma/Gitano community. As 
previously mentioned, most families restrict young girls' behaviour on social media and even their access to smartphones as they tend to keep them from having contact with non-Gitanos and arranged marriages are still common within the community. The boys' discourses contained ample evidence of their attitude and behaviour towards their sisters, with extensive references to protecting them both online and offline. On the one hand, they tend to try to prevent the girls from contacting people from outside their community; on the other, they regulate the type of images or pictures they share online. Pre-marital sexual activity is a strict taboo for young women and would bring shame on them and their family (Powell, 2016), with boys taking an active part in the control mechanisms applied to girls' behaviour.

Interviewer: Have you said anything to your sister about how to use the mobile or the Internet?

Yes, I have. Because she's a girl and I'd be worried; there are some really crazy people out there. I'm afraid of her going on Instagram or Facebook....I'm afraid she'd run into that stuff. (Boy, 16 years)

They also discourage contact with other girls who are not members of their own community. Some boys even mention that their sisters are never allowed to leave the house on their own. Some girls are only allowed to go straight from home to school and vice versa.

Here, one observes certain problems related to new communication technologies which also exist in society as a whole, but which are more accentuated among the Roma/Gitano community. For example, both children and educators mention the way in which husbands and boyfriends control their partners' mobiles and their passwords on social media. Although these situations are clearly far from being exclusive to the Roma/Gitano community, they need to be highlighted in order to target interventions for empowering Roma women.

As soon as the woman got married, her husband had a sort of control over her mobile. He'd have physical control over her mobile and there were a lot of cases of sharing Facebook accounts. They just had the one account. In other words, they weren't individuals any more. There was a lot of control. They need to know what their wives are doing so they shared the password. It was a shared account. (Educator at the Roma Secretariat Foundation)

The girls themselves criticize many non-Gitano girls for posting inappropriate pictures and for their sexual behaviour online. They see them as being "easy" for "doing whatever they want and uploading it". They say that neither they nor any other girls from their community would ever behave that way. In this way, they adhere to their communities' shame-related rules and disidentify themselves from the behaviour of non-Gitanos.
Another striking feature, in keeping with the general lack of interest in job seeking, was that very few girls expressed any intention of finding a job in the future. Those who did tended to mention occupations closely related to traditional female roles, such as teaching or caring for small children and hairdressing. It was also interesting to note the importance some girls gave to the idea of romantic love, mentioning the potential of running away with a boy they liked so that their families would force them to get married.

\section{Conclusions}

In developed countries, the "digital divide" has changed from referring to a lack of access to technological devices to the lack of digital skills in the use of such devices. This has important consequences when it comes to using and getting the most out of the Internet, particularly in areas of education, personal and professional training, and future employment. Although most of the children interviewed had a smartphone for their own use, in terms of digital provision, few had laptops or desktop computers at home. As a result, their use of such devices, which are more closely associated with creativity and learning processes (Vincent \& Haddon, 2018), is limited to the school environment. This absence of computers in the home is a significant barrier to their school work. The education system does not appear to be well positioned to stimulate the development of digital skills among these children; the use of devices during the years of mandatory schooling is very limited; moreover, this group has a very high early school drop-out rate. The general lack of commitment to formal-particularly secondary-education among these children should be a cause for concern given the likely consequences for their vocational development and subsequent social inclusion. Nevertheless, some Roma/Gitano young people are performing outstandingly well at university and are very active among institutions supporting their communities.

Regarding participation, smartphones are used predominantly for recreational purposes. The interviewees' most frequent activities focus on the more common applications and platforms. However, these activities are very limited and their searches centre on fashion/beauty, football, and music. School resources have been shown to be insufficient to motivate or help the majority of Roma/Gitano children develop digital skills that might allow them to become expressive and active creators of their own online content. In short, although these children have access to devices, inequality essentially takes the form of an absence of digital skills that could allow them to benefit from other opportunities provided by the digital environment.

As for protection, this group displays a striking level of digital vulnerability in relative terms, with families rarely regulating their use of technology. Most parents lack the digital skills to be able to supervise or mentor their children's online activity. In short, their incipient 
digital literacy has basically been self-taught, since they lack support from adults with skills in this area.

Although the use of interviews and the focus on the three Ps have helped to focus our attention on the children as individuals, it is also important to bear in mind that, the girls certainly, are all affected by gender inequality. On one hand, it takes the form of control exercised by families over girls, who sometimes have to share their devices, are often prohibited from having a presence on social media in order to "protect them", a prohibition which is subsequently maintained by their husbands. On the other hand, there is an evident lack of interest among most girls in vocational education. Both issues highlight the need to empower Roma/Gitano girls to allow them to develop as autonomous individuals within online and offline environments. Unless this gender gap is bridged, women may become excluded from the increasingly digitalized societies and economies in the near future. As stated in The Mobile Gender Gap (GSMA, 2018) report, concerted action is needed to reduce and ultimately eliminate the gender gap in mobile ownership and use. Successfully doing so will provide substantial benefits to women, their families and their communities, and will be an effective way of contributing to achieving the United Nations Sustainable Development Goals (SDGs). We need to keep in mind that the mobile phone also has the power to transform lives. It can empower women by making them feel safer and more connected, by providing access to information and services, as well as life-enhancing opportunities such as health information, financial services, and employment opportunities. In fact, there is evidence showing an increasing number of Roma women participating in the labour market in the UK (Greenfields, Ryder, \& Smith, 2012) as well as being involved in Roma activism (Powell, 2016). As far as our findings are concerned, we also gathered some evidence showing some women's awareness of their own need for self-empowerment.

In any case, the most significant element is the position they occupy as a group in the social structure. As Salemink (2016) argues, the families' social positiongender, ethnic background, and social class-determines the digital capacities and skills of the individuals. The families of nearly all the interviewees were in receipt of welfare benefits, underlining their economic and social vulnerability. Given the evidence that these elements can hold back the development of digital skills among families at risk of social exclusion, Salemink argues that there is a particular need for digital training and empowerment. This process of empowerment is an urgent necessity requiring the provision of resources and a clear commitment from government to digital literacy, in order to minimise inequality and the knowledge divide and to foster greater social justice (Stoilova, Livingstone, \& Kardefelt-Winther, 2016). If such action is not taken, the relative disadvantage suffered by Roma children in respect of their digital and social insertion is likely to increase.
The authors fully share the broad social consensus regarding education as being one of the essential pillars of the knowledge society, as well as education's influence on social inclusion and progress (Granados, 2008, p. 440). In the future, more funding should be allocated to promoting educational activities outside the formal school system. As stated in Save the Children $(2017$, p. 4) report regarding increased emphasis on life-long and nonformal learning:

The widespread recognition that much education is delivering neither on the employment needs of economies, nor the social and cultural needs of young people will lead to much greater emphasis on life-long learning and the full continuum of education including non-formal learning. The important objective for childhood learning will be to give children the foundational skills to be able to learn creatively for themselves in the future. Non-formal learning and learning that takes place out of school will become increasingly recognised, with new types of certification being developed to measure and reward this. Young children will have the potential to learn wherever they are, not only in schools but also in the fields where they help sow and harvest, or on the streets where they work for a living.

This kind of initiative could take a similar form to the mentorship experiences mentioned by Toyama (2015, p. 200), whose main purpose is to nurture intrinsic growth among mentors as well as mentees: "Mentorship would help people meet the substance of the aspiration. It would help people increase their knowledge, self-confidence, earning power or social influence". Obviously, these non-formal learning initiatives could contribute to developing the Roma/Gitano children's digital skills and, therefore, provide them with better chances to join the labour market and self-employment; as the flexible occupations they traditionally preferred are becoming more and more difficult to pursue (Powell, 2016).

We believe that effective digital inclusion initiatives for Roma/Gitano boys and girls should focus on families, outside the school environment, where people of different ages with shared needs or interests from the same community or family could learn together. A number of interesting experiments are being developed in certain autonomous communities in Spain, where the careers and achievements of people from the Roma/Gitano community are showcased and praised in order to provide children with successful role models from their own community. Therefore, ICTs can provide them with more suitable accommodation that should meet their cultural preferences (Powell, 2016).

\section{Acknowledgements}

The research for this article has been mainly funded by UNICEF, our team has also been funded by the Depart- 
ment of Education of the Basque Government and by the Spanish Ministry of Economy and Innovation.

\section{Conflict of Interests}

The authors declare no conflict of interests.

\section{References}

Boyd, D., \& Ellison, N. (2007). Social network sites: Definition, history and scholarship. Journal of ComputerMediated Communication, 13(1), 210-230.

De Swaan, A. (1997). Widening circles of disidentification: On the psycho- and sociogenesis of the hatred of distant strangers-Reflections on Rwanda. Theory, Culture and Society, 4, 105-122.

Fox, J. E., \& Vermeersch, P. (2010). Backdoor nationalism. European Journal of Sociology, 50, 325-357.

Fundación Foessa. (2014). VII Informe sobre exclusión y desarrollo social en España. Madrid: Cáritas Española Editores. Retrieved from www.foessa2014. es/informe/uploaded/descargas/VII_INFORME.pdf

Fundación Secretariado Gitano. (2013). El alumnado gitano en secundaria. Un estudio comparado [The gitano students in Secondary Education. A comparative study]. Madrid: Ministerio de Educacíon, Cultura y Deporte. Retrieved from www.gitanos.org/ upload/42/08/EstudioSecundaria_InformeEjecutivo. pdf

Garmendia, M., Jiménez, E., Casado, M., \& Mascheroni, G. (2016). Net Children Go Mobile: Riesgos y oportunidades en internet y el uso de dispositivos móviles entre menores españoles (2010-2015) [Net children go mobile: Risks and opportunities on the internet and the use of mobile devices among Spanish minors (2010?2015)]. Madrid: red.es, University of the Basque Country and Euskal Herriko Unibertsitatea.

Gilbert, M. (2010). Theorizing digital and urban inequalities: Critical geographies of 'race', gender, and technological capital. Information, Communication and Society, 13, 937-955.

Gmelch, S. B. (1986). Groups that don't want in: Gypsies and other artisan, trader and entertainer minorities. Annual Review of Anthropology, 15, 307-330.

Granados, J. M. (2008). La alfabetización tecnológica y el acceso a las TIC en la dialéctica inclusión/exclusión. EI caso de la minoría gitana. Revista de Educación, 346, 427-454.

Greenfields, M., Ryder, A., \& Smith, D. (2012). Economic inclusion. In J. Richardson \& A. Ryder (Eds.), Gypsies and travellers: Empowerment and inclusion in British society (pp. 101-118). Bristol: Policy Press.

GSMA. (2018). Connected women. The mobile gender gap report 2018. GSMA. Retrieved from www.gsma.com/mobilefordevelopment/connectedwomen/the-mobile-gender-gap-report-2018

Haddon, L. (2015). Children's critical evaluation of parental mediation. Cyberpsychology: Journal of
Psychosocial Research on Cyberspace, 9(1). http:// dx.doi.org/10.5817/CP2015-1-2

Halford, S., \& Savage, M. (2010). Reconceptualizing digital social inequality. Information, Communication \& Society, 13, 937-955.

Kleine, D. (2013). Technologies of choice? ICTS, development, and the capabilities approach. Cambridge, MA: MIT Press.

Leblon, B. (1993). Los gitanos de España [The gitanos in Spain]. Barcelona: Gedisa.

Mariën, I., \& Prodnik, I. (2014). Digital inclusion and user (dis)empowerment: A critical perspective. Info, 16, 35-47.

Mascheroni, G., \& Cuman, A. (2014). Net children go mobile: Final report. Milano: Educatt.

Matras, Y. (2014). I met lucky people: The story of Romani gypsies. London: Allen Lane.

Nerfin, M. (Ed.). (1977). Another development: Approaches and strategies. Uppsala: Dag Hammarsköld Foundation.

Okely, J. (1983). The traveller-gypsies. Cambridge: Cambridge University Press.

Oleaque, J. M., \& Moreno, C. (2017). Del estereotipo gitano en la prensa de referencia al "Yo no soy trapacero" de las redes sociales. Caso de estudio sobre la imagen y la representación mediática de una minoría étnica. Sistema, 246, 81-96.

Powell, R. (2013). Loïc Wacquant's "ghetto" and ethnic minority segregation in the UK: The neglected case of gypsy-travellers. International Journal of Urban and Regional Research, 37, 115-134.

Powell, R. (2016). Gypsy-travellers/Roma and social integration: Childhood, habitus and the "we-l balance". Historical Social Research, 41(3), 134-156.

Salemink, K. (2016). Digital margins: Social and digital exclusion of Gipsy-travellers in the Netherlands. Environment and Planning, 48(6), 1170-1187.

Save the Children. (2017). The future of learning and technology in deprived contexts. Save the Children. Retrieved from resourcecentre.savethechildren.net/ sites/default/files/documents/the_future_of_learn ing_and_technology.pdf

Sen, A. (1999). Development as freedom. Oxford: Oxford University Press.

Sen, A. (2009). The idea of justice. London: Penguin.

Sibley, D. (1987). Racism and settlement policy: The state's response to a seminomadic minority. In P. Jackson (Ed.), Race and racism (pp. 74-87). London: Unwin Hyman.

Sibley, D. (1998). Problematizing exclusion: Reflections on space, difference and knowledge. International Planning Studies, 3, 93-100.

Stoilova, M., Livingstone, S., \& Kardefelt-Winther, D. (2016). Global Kids online: Researching children's rights globally in the digital age. Global Studies of Childhood, 6(4), 455-466.

Townsend, L., Sathiaseelan, A., Fairhurst, G., \& Wallace, C. (2013). Enhanced broadband access as a solution to 
the social and economic problems of the rural digital divide. Local Economy, 28, 580-595.

Toyama, K. (2015). Geek heresy: Rescuing social change from the cult of technology. New York, NY: Public Affairs.

UN. (1992). Agenda 21: Rio declaration on environment and development. Rio de Janeiro: United Nations.

UNICEF. (2014). Convention on the rights of the child. UNICEF. Retrieved from www.unicef.org/crc/ index_30228.html

UNICEF. (2018). Los niños y niñas de la brecha digital en España [Children on the digital divide in Spain]. Madrid: UNICEF.

Van Deursen, A., \& Van Dijk, J. (2013). The digital divide shifts to differences in usage. New Media and Society,
$16,507-526$.

Van Dijk, J. (2005). The deepening divide: Inequality in the information society. Thousand Oaks, CA: Sage Publishing.

Vincent, J., \& Haddon, L. (2018). Smartphone cultures. New York, NY: Routledge.

Wacquant, L. (2012). A Janus-faced institution of ethnoracial closure: A sociological specification of the ghetto. In R. Hutchinson \& B. D. Haynes (Eds.), The ghetto: Contemporary global issues and controversies (pp. 1-32). Boulder: Westview.

Wilkinson, R., \& Picket, K. (2009). The spirit level: Why more equal societies almost always do better. London: John Allen.

\section{About the Authors}

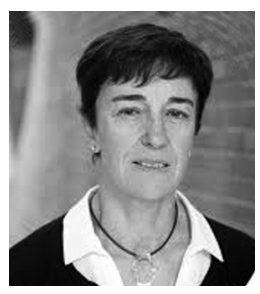

Maialen Garmendia (PhD) is Senior Lecturer in Sociology at the Faculty of Education, Philosophy and Anthropology, University of the Basque Country. Her interests are in social research techniques, audience research, and digital technologies in everyday life. Since 2006 she has been a member of the EU Kids Online network. She also coordinated the Net Children Go Mobile project in Spain.

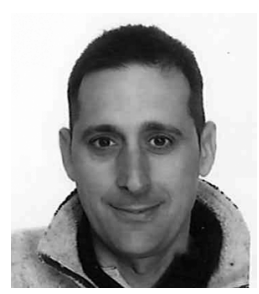

Inaki Karrera (PhD) is Lecturer in Didactics and School Organization at the Faculty of Education, Philosophy and Anthropology, University of the Basque Country, in Donostia-San Sebastián. He has taken part in several research projects at the European (Socrates-Grundtvig 2010-1-FR1-GRU06-002531 ), country and local level. His main research interests are related to educational inclusion and innovation, the digital divide, and social inequality. 